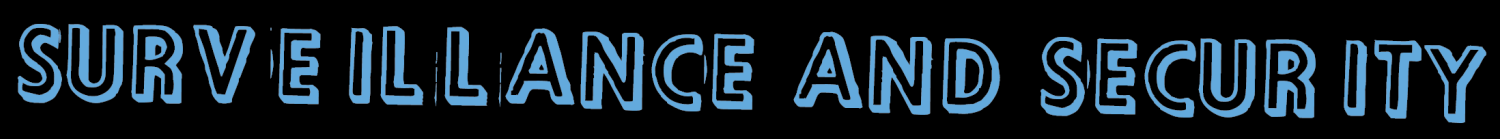 \\ GE:G 3030 \\ CR IMI 3030
}

Spring-2010

Schedule:

Location:

Professor:

Office:

Office Hours:

Email:

Twitter:
Wednesday: 11:20 AM - 1:55 PM

ZEN 209

Richard Nisa

Mansion 38A

Wednesdays - 10:00AM - 11:00 AM

nisa@fdu.edu

twitter.com/nisaface

"Unfortunately, security and liberty form a zero-sum equation. The inevitable trade-off: To increase security is to decrease liberty and vice versa. - Walter Cronkite, journalist

"We only need refer to the necessary controls and constraints of the railway, airway or highway infrastructures to see the fatal impulse: the more speed increases the faster freedom decreases."

- Paul Virilio, Speed and Politics

"Never underestimate the willingness of the American public to tell you about itself."

- Direct-marketing executive 


\section{Course Description:}

Recent revelations about data collection by actors as varied as the National Security Agency and Facebook have challenged many of our most basic beliefs about power and privacy. It is increasingly clear that our bodies, images, and words are ceaselessly tracked, sorted, profiled, stored in databases, and recalled by algorithms-all in the name of a loosely defined concept called 'security'. In this class, we will interrogate these uneasy relationships between surveillance and security, looking at both state surveillance practices as well as visual practices aimed at monitoring the state. By engaging with a broad array of media - academic research, social theory, television, film, fiction - we will debate the role of surveillance in generating security, but also focus on the ways that broad data collection can actually enable populations to act in new and beneficial ways.

\section{Course Objectives:}

The aim of this course is twofold:

1. To critically interrogate ideas like power, freedom, control, privacy, paranoia, and others as they mobilize discourses of security and relate to practices of surveillance. We will do this by way of several disciplinary frameworks - most commonly geography, but also sociology, anthropology, architecture, philosophy, literature and popular culture. Upon completing the course, you will have a more complete understanding of the geographical complexities and contradictions of practices of surveillance in the name of security.

2. To explore the use of surveillance technologies and practices in a number of historical, social, and global contexts. In each setting, the role of individuals relative to their state and to matters of their own privacy is significantly different. In addressing these issues from a number of vantage points, you will come away with an increased technological literacy that will enable you to move away from any kind of all-or-nothing understanding of the advantages and disadvantages of surveillance power. 


\section{Readings:}

There is no "textbook" to purchase for this class. However, I would like you to purchase one inexpensive (currently under $\$ 15$ new; under $\$ 10$ used; under $\$ 12$ as an ebook) book that will serve to ground our reading and discussion during the second half of the semester.

Dave Eggers, The Circle, 1st edition (New York: Vintage Books, 2014) ISBN-10: 0345807294 // ISBN-13: 978-0345807298

Al1 other readings are located on our class Blackboard site or available for download from the FDU library/e-brary. Readings will be drawn from a range of sources: academic articles and book excerpts, newspapers and magazine reportage, and fiction. Some of the readings are quite dense, and will require careful reading and reflection. If you put in the effort, the reward for close reading extends far beyond the walls of our classroom.

Complete all readings and assignments prior to the class meeting for which they are scheduled and BRING A COPY OF THE READINGS TO CLASS. We will be referring to the articles in our lectures and class discussions, so having the readings with you will enable you to follow along, take notes, and make meaningful contributions to class discussions. You should complete the assigned readings before each class and to use these readings to frame questions for discussion each week.

\section{Writing Assignments:}

I am a firm believer that writing is one of the keys to engaged and nuanced critical thinking. To that end, in the class our writing assignments have an emphasis on process as well as product.

A. TRACKING 24 HOURS (TWICE):

During the first few weeks of class, I'd like you to begin thinking about your own relationships to surveillance and power, and to write a paper that details these connections. This includes consideration of what types of surveillance technologies and practices are directed at you, but also those that you actively participate in on a daily basis because you want to. Finally, some thought must be given to the uses to 
which your data are put, and how you might resist these forms of surveillance. This is not necessarily a research paper (though you will likely need to start doing some exploration), but an engagement with your personal relationships to power, visibility, and control. Be creative, too: consider using images and maps, downloading a tracking app or looking into your FitBit data. (FORMAT: 2-3 pages, double-spaced, Times New Roman in 12 point font, one inch margins on the top and bottom, 1.25 on the sides).

Due: February 24 .

Towards the end of the semester, we will do this exercise again, this time with the benefit of a semester discussing and learning about the world of surveillance. For the second iteration of the project, in addition to revisiting and expanding your engagement with your surveillance profile, I'd like you to also add a page about how your understanding of surveillance, tracking, and monitoring has changed.

(FORMAT: $3-4$ pages, double-spaced, Times New Roman in 12 point font, one inch margins on the top and bottom, 1.25 on the sides).

Due: May 4 .

\section{B. DISCUSSION PROMPTS :}

Please write a total of five (5) short reactions to the articles we've read for that day's class (FORMAT: 400-500 words, double-spaced, Times New Roman in 12 point font, one inch margins on the top and bottom, 1.25 on the sides). I am looking for some sort of critical engagement with the readings: I DO NOT WANT A 'BOOK REPORT'. You are only to hand in one response per week, it must address that week's readings, and only one paper will be given credit per week.

Reaction papers will be evaluated based on three criteria:

1. Your CRITICAL thoughts on the reading/readings. Any summarizing text should amount to no more than a sentence or two.

2. Address the ways in which the reading affected you and your understanding of development, poverty, or inequality. For example, you might choose to highlight something new that you learned or how the reading shifted your perspective or raised questions. Or you might explore how power dynamics are evident in the text.

3. Find one short passage in which the author addresses a key idea or theoretical approach. Analyze this passage by 
referring to other parts of the text, to class

discussions, or to events happening in the world. In

distinction to an exploration of how we personally engage with the text (see point 2 above), this process is aimed at fostering your ability to read actively and critically, to find patterns or contradictions in a piece of writing, and to construct analytical arguments.

4. Grammar, composition, spelling and clarity.

C. (GROUP?) RESEARCH PROJECT:

This semester, in groups of 4 or 5 or alone (we will vote), we will work on writing one analytical essay the final draft of which will be due on April 13. Because research and writing are processes that take time, this single paper will take shape over the course of the entire semester, by way of a number of short assignments and peer review sessions. The parameters of this project will be described in class.

The final essay will be 20-25 pages (for groups) or 8-10 pages (if the class choses the 'sole authorship' route). Either way, we will be breaking the paper up into a number of small parts and working with each other to develop and improve the end result. Two printed copies of all assignments are to be passed in at the beginning of class. Late students and/or late assignments will earn a reduction of $25 \%$ off of their grade for that assignment.

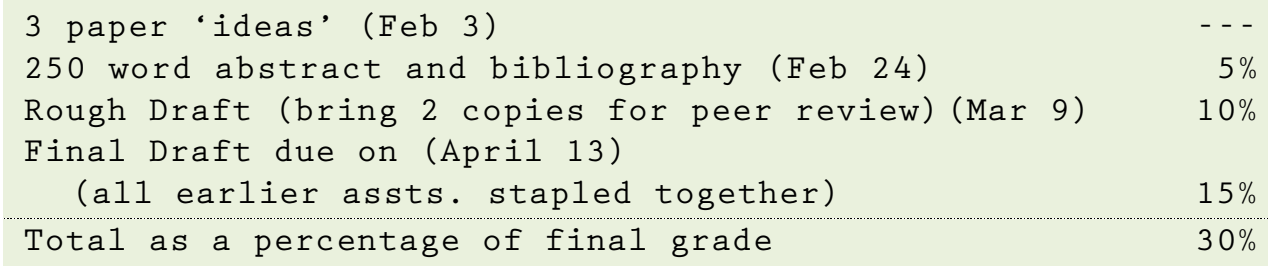

Each essay must have an original title, be stapled, typed in 12 -point font, double-spaced, with standard margins and a works cited list. I grade for analysis and content as well as style and grammar, and will provide you with a simple grading matrix to help you along. To that end, you are encouraged to visit me during office hours and/or use the tutors at the Academic Support Center. Late papers will only be accepted for one week after due date with $20 \%$ reduction in the grade. After that, you will not receive points for the paper. 
There is no final exam for this course. Instead, you will be asked to write a short paper that connects a theme from Dave Eggers, The Circle (a satirical work of semi-sci-fi fiction) to an actual set of issues, events, companies, or people. More information will be give on this as we begin to read Eggers' book later in the semester. This will be due during the final exam period on May 11 .

Attendance and Participation:

Attendance and active participation are compulsory in this class. You are required to arrive on time, contribute to our discussions and in-class projects, and stay for the duration of the class. You are allowed one unexcused absence in the course (an excused absence is a documented medical or family emergency as determined by the Dean of Students Office). Each additional unexcused absence will result in the loss of 4 points from your attendance and participation grade (there are a total of 20). Late arrivals and early departures will count as $1 / 2$ an absence. Four unexcused absences will result in the automatic failure of the course. You are responsible for finding out what you missed while absent and getting the notes from a classmate. There are no make-up quizzes in this class.

\section{Class protocols:}

The following protocols hold, without exception, for all students in this class:

1. Collegiality and common sense require that you turn off your cell phone in the classroom. If your cell phone rings in class, I will ask you to leave, and you will earn $1 / 2$ absence for the day.

2. Laptops and other devices are welcome (indeed encouraged) in the classroom. However, they must be used in a manner that is respectful towards the rest of us. If you are using one of these devices, my expectation is that you will use it to take notes. Using your portable devices for other reasons (surfing, texting, email, videos) is a distraction for you (obviously) and your peers. If I detect that you are using your portable devices for any of these other activities, I will ask you to leave and you will lose the right to bring the device to class again. Additionally, you will earn $1 / 2$ absence for the day. 
3. Respect is paramount. We will be discussing and debating issues in this class that have no clear or inevitable 'answers' yet still generate impassioned and/or emotional responses. Please be mindful of others as we work to develop an open-yet-critical classroom culture.

4. Visit me during office hours. I am more than happy to review material and answer questions. If you cannot make posted hours, we can try to arrange an alternative appointment time.

Grading criteria:

Attendance, Participation, Reading Quizzes 20\%

$\begin{array}{ll}\text { Tracking } 24 \text { Hours (part I) } 10 \% & 10 \%\end{array}$

$\begin{array}{ll}\text { Tracking } 24 \text { Hours (part II) } 10 \% & 10 \%\end{array}$

Response Papers (5 @ 4\% each) $20 \%$

Analytical Paper $30 \%$

$\begin{array}{ll}\text { Final Synthesis Paper } & 10 \%\end{array}$

Total $100 \%$

Grade determination:

There is no extra credit given in this course.

The numeric grades correspond to the following letter grades:

\begin{tabular}{|lllll|}
\hline A & $95-99 \%$ & C+ & $77-79 \%$ \\
A- & $90-94 \%$ & C & $73-76 \%$ \\
B+ & $87-89 \%$ & C- & $70-72 \%$ \\
B & $83-86 \%$ & D & $60-69 \%$ \\
B- & $80-82 \%$ & F & Less than $60 \%$ \\
\hline
\end{tabular}

Academic Integrity:

Cheating, plagiarism, or other violations of academic integrity will not be tolerated. To that end, if you haven't already done so, please become familiar with FDU's Academic Integrity Policy. Any and all students in violation of this policy will be subject to automatic failure of the course for a first offense, and will be suspended from the university for a second offense. The inability to prove authorship when questioned about your work's authenticity could be grounds for the charge of plagiarism. It is entirely your responsibility to read the FDU Academic Integrity Policy carefully and abide by it. 
Disability Disclosure:

Fairleigh Dickinson University - College at Florham, in accord with the policies underlying Section 504 of the Rehabilitation Act of 1973, Americans with Disabilities Act (ADA) of 1990 and ADA Amendments Act (ADAAA), works to ensure that reasonable accommodations are implemented for enrolled students with documented disabilities to function in the academic environment. Any student with documented disabilities, who feels he/she may need academic accommodations while taking this course, should first contact the office of Disability Support Services at 973443-8079 to discuss his/her specific needs. Once the disability is verified, pick-up your letters from the office of Disability Support Services, then make an appointment to see the professor.

Visit http://view.fdu.edu/default.aspx?id=3344 for more information. 


\section{GREETING}

January 27 - Introductions: What Does Seeing Do?

\section{SEEING}

February 3 - Panopticism, Security, and Control: Theoretical Foundations and Surveillance Studies

Gilliom, John, and Torin Monahan. "Introduction," in SuperVision: An Introduction to the Surveillance Society. Chicago: The University of Chicago Press, 2013. (1-10)

Foucault, Michel. Discipline \& Punish: The Birth of the Prison. Vintage Books, 1979. (195-228)

Kevin Kelly, "Why You Should Embrace Surveillance, Not Fight It," WIRED, March 10, 2014, http://www.wired.com/2014/03/going-tracked-heres-way-embrace-surveillance/.

\section{HIDING}

February 10 - Privacy, Trade-Offs, Camouflage: On the Use and Abuse of Surveillance for Security

Great Britain Air Raid Precautions Dept, Camouflage of Large Installations (H. M. Stationery off., 1939).

Solove, Daniel J. "Values: How We Should Assess and Balance the Values of Privacy and Security," in Nothing to Hide: The False Tradeoff between Privacy and Security. New Haven [Conn.]: Yale University Press, 2011. (21-52)

Monahan, Torin. "Questioning Surveillance and Security," in Surveillance and Security: Technological Politics and Power in Everyday Life. New York: Routledge, 2006.(1-23)

\section{RULING}

February 17 - Histories of State Surveillance 1: Seeing Like a State, Seeing Like an Empire

Sa'di, Ahmad H. "Colonialism and surveillance" in David Lyon, Kevin Haggerty, and Kirstie Ball, Routledge Handbook of Surveillance Studies (Routledge, 2012). (151-158)

Joseph, Anne M. “Anthropometry, the Police Expert, and the Deptford Murders: The Contested Introduction of Fingerprinting for the Identification of Criminals in Late Victorian and Edwardian Britain," in Caplan, Jane, and John Torpey. Documenting Individual Identity: The Development of State Practices in the Modern World. Princeton, N.J.: Princeton University Press, 2001.

Scott, James C. Seeing Like a State: How Certain Schemes to Improve the Human Condition Have Failed. Yale University Press, 1999. (11-25) 


\section{SORTING}

February 24 - Histories of State Surveillance 2: Domestic Surveillance and the Making of the United States

Parenti, Christian. The Soft Cage: Surveillance in America from Slavery to the War on Terror. Basic Books, 2003. (13-42; 61-76)

David P. Hadley. "America's "Big Brother": A Century of U.S. Domestic Surveillance." Origins: Current Events in Historical Perspective 7, no. 3 (2013): n.p. http://origins.osu.edu/print/2232

Theoharis, Athan G. "FBI Surveillance during the Cold War Years: A Constitutional Crisis." The Public Historian 3, no. 1 (January 1981): 4-14.

\section{SECURING}

March 2 - War and Security 1: The NSA, PRISM, and Top Secret America

Bamford, James. "They Know Much More Than You Think," The New York Review of Books, August 15, 2013, http://www.nybooks.com/articles/2013/08/15/nsa-they-know-much-more-you-think/.

Lepore, Jill. "The Prism." The New Yorker, June 24, 2013.

http://www.newyorker.com/reporting/2013/06/24/130624fa_fact_lepore?currentPage=all

Priest, Dana, and William M. Arkin. Top Secret America: The Rise of the New American Security State. 1st ed. Little, Brown and Company, 2011.

Electronic Frontier Foundation: Timeline of NSA Spying : https://www.eff.org/nsa-spying/timeline

\section{BOMBING}

March 9 - War and Security 2: Aerial Surveillance and Life Under the Drone

Grégoire Chamayou, A Theory of the Drone (New York: The New Press, 2015). (37-51)

Atef Abu Saif, The Drone Eats with Me: Diaries from a City Under Fire (Comma Press, 2015).(19-21, 28-32)

Anderson, Kenneth. The Case for Drones. SSRN Scholarly Paper. Rochester, NY: Social Science Research Network, June 1, 2013. http://papers.ssrn.com/abstract=2047537.

Alison J. Williams, "Re-Orientating Vertical Geopolitics," Geopolitics 18, no. 1 (January 2013): 225-46.

\section{RESTING}

SPRING BREAK: March 16 : NO CLASS 


\title{
MOVING
}

March 23 - Seeing Movement: Globalization, Migration, Borders

Amoore, Louise. "Biometric Borders: Governing Mobilities in the War on Terror.” Political Geography 25, no. 3 (March 2006): 336-351.

Nellis, Mike."24/7/365: mobility, locatability and the satellite tracking of offenders," in Aas, Katje Franko. Technologies of Insecurity: The Surveillance of Everyday Life. [S.1.]: Routledge Cavendish, 2010. (105124)

James Temperton, "One Nation under CCTV: The Future of Automated Surveillance (Wired UK)," Wired UK, August 17, 2015, http://www.wired.co.uk/news/archive/2015-08/17/one-nation-under-cctv.

Katja Franko Aas, “'Crimmigrant' Bodies and Bona Fide Travelers: Surveillance, Citizenship and Global Governance,” Theoretical Criminology 15, no. 3 (August 1, 2011): 331-46.

\section{POLICING}

\author{
March 30 - Crime, Policing, and Surveillance Power
}

Justin Jouvenal, “The New Way Police Are Surveilling You: Calculating Your Threat 'score,” The Washington Post, January 10, 2016, https://www.washingtonpost.com/local/public-safety/the-new-waypolice-are-surveilling-you-calculating-your-threat-score/2016/01/10/e42bccac-8e15-11e5-baf4bdf37355da0c_story.html

Samuel Tanner and Michaël Meyer, "Police Work and New 'security Devices': A Tale from the Beat," Security Dialogue 46, no. 4 (August 1, 2015): 384-400.

Morozov, Evgeny. "Less Crime, More Punishment," in To Save Everything, Click Here: The Folly of Technological Solutionism. New York: Public Affairs, 2013.

\section{CONSUMING}

\author{
April 6 - Data Shadows, Identity, and the Economy
}

Dave Eggers, The Circle, 1st edition (New York: Vintage Books, 2014).

Singh, Sachil and David Lyon. "Surveilling Consumers: The Social Consequences of Data Processing on Amazon.com," In Belk, Russell W., and Rosa Llamas. The Routledge Companion to Digital Consumption. Routledge, 2013. (319-332)

Gilliom, John, and Torin Monahan. "It's in the Cards," in SuperVision: An Introduction to the Surveillance Society. Chicago: The University of Chicago Press, 2013. (1-10)

Koskela, Hille. "You shouldn't wear that body," in David Lyon, Kevin Haggerty, and Kirstie Ball, Routledge Handbook of Surveillance Studies (Routledge, 2012). (49-56) 


\title{
CONNECTING
}

April 13 - Life, Love, and Labor in the Age of Social Media

Dave Eggers, The Circle, 1st edition (New York: Vintage Books, 2014).

Rob Horning, "Single Servings," The New Inquiry, February 12, 2013,

http://thenewinquiry.com/essays/single-servings/.

Frank Pasquale, “The Other Big Brother,” The Atlantic, September 21, 2015,

http://www.theatlantic.com/business/archive/2015/09/corporate-surveillance-activists/406201/.

Katz, Cindi. "Me and My Monkey: What's Hiding in the Security State?" in Dr Rachel Pain and Professor Susan J. Smith, Fear: Critical Geopolitics and Everyday Life (Ashgate Publishing, Ltd., 2012). (59-70)

\section{LIBERATING}

\author{
April 20 - Surveillance, Freedom, and Democracy
}

Dave Eggers, The Circle, 1st edition (New York: Vintage Books, 2014).

Bonde Thylstrup, Nanna. "The Invisibilities of Internet Censorship," In Invisibility Studies: Surveillance, Transparency and the Hidden in Contemporary Culture, (Oxford ; New York: Peter Lang AG, Internationaler Verlag der Wissenschaften, 2014). (301-320)

Walter Kirn, "If You're Not Paranoid, You're Crazy," The Atlantic, November 2015, http://www.theatlantic.com/magazine/archive/2015/11/if-youre-not-paranoid-youre-crazy/407833/.

Kevin Haggerty, Surveillance and Democracy, June 11, 2010 (Abingdon, Oxon England ; New York: Routledge-Cavendish, 2010). (1-14)

\section{TRACKING}

\author{
April 27 - Between Terrorist Finance and FitBit
}

Dave Eggers, The Circle, 1st edition (New York: Vintage Books, 2014).

Kate Crawford, Jessa Lingel, and Tero Karppi, "Our Metrics, Ourselves: A Hundred Years of Self-Tracking from the Weight Scale to the Wrist Wearable Device," European Journal of Cultural Studies 18, no. 4-5 (August 1, 2015): 479-96

Whitson, Jennifer. "Foucault's FitBit: Governance and Gamifiction," in Steffen P. Walz and Sebastian Deterding, eds., The Gameful World: Approaches, Issues, Applications (Cambridge, Massachusetts: The MIT Press, 2015).

Mya Frazier, “The Data-Driven Parent," The Atlantic, May 2012, http://www.theatlantic.com/magazine/archive/2012/05/the-data-driven-parent/308935/. 


\section{ESCAPING}

May 4 - Ubiquitous Surveillance and the Internet of Things

Dave Eggers, The Circle, 1st edition (New York: Vintage Books, 2014).

Fernback, Jan. "Sousveillance: Communities of Resistance to the Surveillance Environment." Telematics and Informatics 30, no. 1 (February 2013): 11-21.

Murakami Wood, David. "Vanishing Surveillance: Ghost-Hunting in the Ubiquitous Surveillance Society," In Invisibility Studies: Surveillance, Transparency and the Hidden in Contemporary Culture, (Oxford ; New

York: Peter Lang AG, Internationaler Verlag der Wissenschaften, 2014). (281-300)

Ian Bogost, "Welcome to Dataland: Design Fiction at the Most Magical Place on Earth," Medium, July 29, 2014, https://medium.com/re-form/welcome-to-dataland-d8c06a5f3bc6\#.agcxaf2fn.

Final: May 11 at $10 \mathrm{am}$ or $12: 30 \mathrm{pm}$ 